\section{Brasil redesenhado: projetos de criação de novos estados e territórios}

Dois decretos legislativos do Congresso Nacional causaram alvoroço em fins de maio e início de junho de 2011. Os decretos de número $136 \mathrm{e}$ 137 , promulgados pelo presidente do Congresso, senador José Sarney (PMDB/AP), autorizavam, respectivamente, a realização de plebiscito sobre a criação dos estados de Carajás e Tapajós no território do Pará. A consulta à população paraense foi marcada para dezembro de 2011. Com a população bastante dividida no plebiscito $66,6 \%$ rejeitaram a criação de Carajás e outras $66,1 \%$ a do Tapajós. Se todos os dez projetos de lei existentes fossem aprovados, o Brasil ganharia sete estados e três territórios (veja mapa).

De acordo com informações da Agência Câmara, são dois projetos de estados e três de territórios na região Norte - do Rio Negro, do Solimões e do Oiapoque -, três estados no Nordeste - Maranhão do Sul, Gurgueia e Rio São Francisco - e outros dois estados no Centro-OesteMato Grosso do Norte e Araguaia. Os estudos de viabilidade do surgimento de novos estados - com foco na Amazônia - estão previstos no

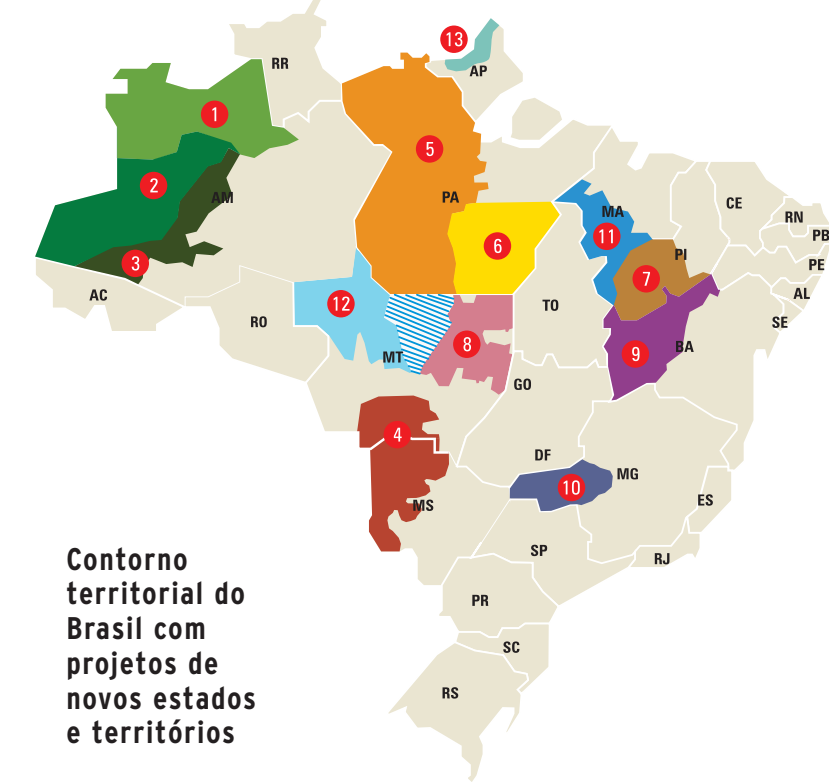

1. Território Federal do Rio Negro

2. Território Federal do Solimões

3. Território Federal do Juruá

4. Território Federal do Pantanal

5. Tapajós

6. Carajás

7. Gurgueia

8. Araguaia

9. Estado do Rio São Francisco

10. Estado do Triângulo

11. Maranhão do Sul

12. Mato Grosso do Norte

13. Território Federal do Oiapoque texto constitucional brasileiro, mas, segundo o deputado Giovanni Queiroz (PDT/PA), não foram levados inteiramente adiante. "Acho que, mais cedo ou mais tarde, o Brasil vai ter de fazer um estudo da revisão geopolítica do país, não só da Amazônia", afirma. Na opinião dele, vários países descentralizam a gestão para facilitar o contato com a população. "A Alemanha, que é duas vezes e meia menor que o Pará, tem 16 estados", nota.

MUDANÇAS NOS REPASSES $O$ processo no Pará é o que se encontrava em estágio mais avançado. Em Marabá, candidata à sede de Carajás, parte da população era favorável à separação porque, de acordo com o prefeito da cidade Maurino Magalhães de Lima, "mesmo sendo uma região rica em recursos minerais e no setor agropecuário, as carências são enor- mes em todas as áreas, os investimentos por parte do Estado sempre foram exíguos". Para Lima, é preciso que os recursos gerados na região tenham reflexo local, ao contrário do que ocorre com o atual repasse.

Segundo a advogada Anna Cruz Silva, de Belém, há outros caminhos que podem solucionar o problema de concentração de infraestrutura e serviços públicos na capital paraense. "A solução proposta, em lugar de retalhar o território e aumentar os custos da máquina para todo o Brasil deveria passar pelo fortalecimento de novas lideranças locais e seus pleitos e por discussões legislativas sobre destinações orçamentárias mais homogêneas", propõe.

Regina Araújo, professora de geografia humana na Universidade de São Paulo (USP) e autora de livros e manuais de geografia do Brasil, 
